\title{
An Empirical Research on Formative Assessment in Senior High School English-Writing Teaching
}

\author{
Yuewei Zhang \\ College of Foreign Languages, Zhaoqing University, Zhaoqing, 526061, China
}

zhangyueweiy@163.com

Keywords: formative assessment; writing reflection ability; writing proficiency

\begin{abstract}
Assessment plays an important role in English teaching process, and according to the instructional functions, is classified into formative assessment and summative assessment. Formative assessment is different from summative assessment in that it is based on teachers and phase tests. Formative assessment is "student-centered" and emphasizes students' learning process. During the learning process, formative assessment is used to assess students' abilities, knowledge, emotion and learning strategies, etc. In this research, the subjects involve 100 senior high school students of two Grade-One classes of Jinzhou city, Liaoning province. One class is the experimental class, which has 49 students and the formative assessment is applied in their English writings. The other is the control class, which has 51 students and the summative assessment is used in their English writings. The instruments of the research are questionnaires and writing tests and writing portfolios. The statistic software SPSS17.0 is used in the research for processing data. The research concludes that after analyzing and comparing the data, the formative assessment helps to improve students’ English writing interest and writing reflection ability and writing proficiency.
\end{abstract}

\section{Introduction}

Writing is considered as an important part of language competence. Therefore, it is very necessary to strengthen students' writing proficiency. At present, English teaching assessment depends greatly on the summative assessment in senior high schools in China. Summative assessment has been widely used for several decades in English writing teaching. It values the writing product rather than writing process. The testing marks are regarded as final assessment criteria, which has given rise to the awareness that students study English just to pass their exams. Conspicuously, students can hardly be motivated with passion to write under the summative assessment. Moreover, many students lose their interests of writing. Teachers focus more on the vocabulary and grammar with the result that students can gain good grades while their writing ability is still far from satisfactory. In such a background, a new kind of assessment-formative assessment has formed and has gradually won its popularity in senior high school English teaching

For the last two decades, summative assessment has been widely employed by people in instruction, which evaluates students' performances and teachers' teaching quality mainly according to testing scores. As a result, English teaching and learning has fallen into an "examination-oriented" mode. Nowadays, writing classes are dominated by teachers, and the main writing evaluation method is summative assessment. Such a method ignores students' roles in learning process and pays no attention to students' attitudes and emotions. With such disadvantages with summative assessment, formative assessment, which emphasizes the writing process, is called for. This research employs formative assessment to improve students' English writing proficiency. The research is to find out the relationship between formative assessment and English writing teaching. It is designed to employ experimental methods to assess students' English writing process and products.

This paper consists of five parts. Part One is the introduction, including the research background, the significance and purpose of the research. Part Two is the introduction to the formative assessment and current methods of English writing teaching. Part Three is the research methodology and research instruments and research procedures. Part Four is the data analysis and 
discussion. Part Five is the conclusion.

\section{Formative Assessment and Current methods of English-Writing Teaching}

Formative assessment is also called classroom assessment or process evaluation. The term is first proposed by Scriven (1967) [1], which means that "by analyzing and diagnosing the problems in the educational process, the ongoing teaching and learning activities will be supplied timely feedback information thus can be helpful to enhance the assessment quality of educational activities". Though Scriven did not present the exact concept of formative assessment, many researchers conducted related researches. Benjamin Bloom (1971) [2] was the first person who applied formative assessment into assessment experiments and boosted its development.

Formative assessment is an essential part of teaching, which mainly concentrates on developing students' learning potential and modifying students' learning. The tasks are to assess students' daily activities, learning attitude and learning strategies, emotion, and achievements. The aim is to give inspirations to students as well as guide students' adjustment in their learning process and build up their confidence. In formative assessment, students take part in the evaluation actively rather than passively.

Formative assessment is an objective and a dynamic assessment. The participants include teachers and students. They play different roles in the evaluation process. Self-assessment, peer assessment and teacher assessment are commonly employed in the classroom evaluation.

Summative assessment refers to the cumulative assessment, usually occurring at the end of a unit or topic coverage, which intends to capture what a student has learned, or the quality of learning, and judge performance against some standards. We often think of summative assessment as traditional objective tests (Atkin, 2003 [3]). The goals of summative assessment are different. Summative assessment can rank or grade a student; can fail or pass a student; can promote progress or predict success for future learning.

It is generally agreed that writing has such a mode: plan-writing-correction. After students hand in their compositions, the teacher may spend about 5minutes to check every composition and give a comment and a mark at the same time. Nevertheless, most of the current fact is that students only look at the mark quickly and set the paper aside. Many students think it useless to spend time on writing. In order to change this prejudice and make students value the writing mark and comment, the teachers' responding ways need to be adjusted.

At present, many students in senior high school consider writing very difficult to grasp. And many English teachers also think that writing is a trouble-maker to teach because of difficulties in the process of writing teaching. Generally, these two methods are affecting the current writing teaching, which involves product method and procedural method. The product method only pays attention to the final result, that is to say, students' composition. Meanwhile, teachers only focus on the correction on sentence structure and grammar when they correct students' writing. In an English writing class governed by product method, after a title or a topic given by the teacher, students write their own composition in class and they must submit their works to the teacher after completing the writing. Then the teacher will correct the mistakes in composition and give a mark and a comment. In the product method, teacher hardly ever teaches students how to write logically.

The other method-procedural method is widely employed in the writing class, which focus more on the writing process rather than the final product (McMillan, 2007 [4]). In an English writing class governed by the procedural method, students will know more knowledge about their writing topic through discussion with teacher. After students' brainstorming of the topic, the teacher encourages students to draft and write and correct their works step by step. The obvious merit of the procedural method is that the teacher introduces students the writing techniques essential to writing (Wiliam, 2011, [5]).

The teacher will find various mistakes in students' composition during the checking stage. Sometimes the grammar in the sentences is right, but the whole sentence is used in Chinese English, which sound awkward to native English speakers. Hence, it will be beneficial for teachers and students to increase the language input and make a harmonious atmosphere so that students can be 
highly-motivated and confident. At the same time, it is pretty useful for students to develop their writing strategies and construct writing knowledge. As a result, students will motivate their writing interests and enhance their writing proficiency as well as develop their comprehensive competence.

\section{Research Methodology and Instruments}

In order to find out whether formative assessment can improve senior high school students' English writing interest and writing reflection ability and enhance students' English writing proficiency, the formative assessment is employed in senior high school English writing teaching in this paper.

The formative assessment method was applied in the English writing class in the experimental class while the summative assessment method was applied in the control class. Research instruments used in this research are majorly the questionnaires and writing tests and writing portfolios. The statistical software SPSS17.0 was used to analyze data in the research. The research participants involved in the study include 100 students from two classes in Grade 1 in Senior High School in China. One class with 49 students was randomly selected as Experimental Class (EC) and the other class with 51 students as Control Class (CC).

In the experimental process, these students of two classes had the same writing textbooks, the same class hours, the same teaching methods but different assessment methods.

In this research, all students in the two classes took part in the writing pre-test and writing post-test. In order to ensure the validity of this study, this study used the writing test papers of college entrance examinations of the past years. Before the experiment, 100 students of the two classes were asked to finish writing pre-test. The writing paper of pre-test was the 2011 English writing of college entrance examination. After the experiment, 100 students of the two classes were required to finish writing post-test. In order to ensure that the difficulty degree of the writing pre-test is equal to the writing post-test, the writing paper of post-test was the 2012 English writing of college entrance examination.

Writing procedures in Experimental Class includes five stages: (1) preparation before writing, in which the teacher gave the writing task to students in the writing class, making students brainstorm and discuss with partners in groups about the writing topic. Students were required to complete the first drafts by themselves within ten minutes. (2) Students' self-assessment, which was finished on the self-assessment sheet after students' first drafts. (3) Peer-assessment, in which the teacher gave each student a peer-assessment sheet, and then let them exchange their first drafts with partners in groups. Then the students need to finish their second drafts according to their own reflections and the suggestions of their partners. (4) Teacher-assessment, in which the teacher collected each student's self-assessment sheets, peer-assessment sheets and their second drafts together. (5) Preserving materials after writing, in which when each writing task was finished, students should preserve their own materials, which contained self-assessment sheets, peer-assessment sheets, teacher-assessment sheets, the first drafts, the second drafts and the final drafts.

Writing procedures in Control Class, in which the teacher provided the writing task, requires that students discuss the writing topic with their partners. After discussion, the students were asked to finish their first drafts. Then students handed in their compositions. The teacher corrected mistakes and gave a mark and a comment on each composition. During the process of correcting students' compositions, the teacher gained teaching reflections and knew how to grasp the corresponding contents of the unit, which includes new expressions and vocabulary, phrases and sentence structures. In the writing class, the teacher provided the comments on students' compositions through the mastering of information, mainly on correcting mistakes. Based on the teacher's comments, students can revise and finish their second drafts by themselves after class. The students returned the second drafts to the teacher for second correct, and the teacher gained teaching reflections from students' compositions and finding out the advantages in students' writings. Meanwhile, the teacher also should present some good compositions to the whole class. Students revised their second drafts after learning from those good compositions and finished the final drafts. 


\section{Results and Discussion}

This part mainly analyzes and discusses the results of questionnaires, pre-test and post-test.

Table 1. Statistics of pre-questionnaire and post-questionnaire in EC (number=49)

\begin{tabular}{|c|c|c|c|c|c|}
\hline Questions & Questionnaire & $\begin{array}{c}\text { Strongly } \\
\text { agree (\%) }\end{array}$ & $\begin{array}{c}\text { Agree } \\
(\%)\end{array}$ & $\begin{array}{c}\text { Disagree } \\
(\%)\end{array}$ & $\begin{array}{c}\text { Strongly } \\
\text { disagree (\%) }\end{array}$ \\
\hline $\begin{array}{c}\text { (1)Are you interested in } \\
\text { English writing? }\end{array}$ & $\begin{array}{c}\text { Pre- } \\
\text { Post- }\end{array}$ & 16 & 18 & 46 & 20 \\
\hline (2) Do you want to improve & Pre- & 14 & 23 & 36 & 27 \\
your English writing ability? & Post- & 15 & 32 & 39 & 14 \\
\hline $\begin{array}{c}\text { (3) Are you positive in } \\
\text { finishing writing task? }\end{array}$ & Pre- & 13 & 27 & 49 & 11 \\
\hline (4) Are you confident in & Pre- & 4 & 31 & 41 & 24 \\
\hline writing? & Post- & 14 & 21 & 47 & 18 \\
\hline $\begin{array}{c}\text { (5)Do you think teacher's } \\
\text { comment important? }\end{array}$ & Pre- & 34 & 28 & 23 & 15 \\
\hline (6) Do you often reflect on & Pre- & 15 & 31 & 40 & 14 \\
\hline $\begin{array}{c}\text { (7) Dour writing? } \\
\text { advantages and disadvantages } \\
\text { in writing? }\end{array}$ & Post- & 22 & 21 & 29 & 39 \\
\hline (8) Do you think it important & Post- & 19 & 14 & 48 & 30 \\
\hline that your partners talk about & Pre- & 11 & 30 & 41 & 13 \\
\hline writing? & Post- & 21 & 35 & 31 & 13 \\
\hline $\begin{array}{c}\text { (9) Do you write draft and } \\
\text { think carefully in writing? }\end{array}$ & Pre- & 6 & 17 & 27 & 50 \\
\hline
\end{tabular}

Note: (number=49) means that 49 students finished the questionnaires.

Table 2 shows the mean value of the pre-and post-test in EC and CC. The mean value of pre-test in EC and CC are very similar, showing that there is no much difference between EC and CC. However, there is a significant difference in EC before and after the experiment. The formative assessment improves students’ writing proficiency in EC.

Table 2. Statistics of pre-and post-test in EC and CC

\begin{tabular}{|c|c|c|c|c|c|c|c|}
\hline & Class & $\mathrm{N}$ & Mean & & Class & $\mathrm{N}$ & Mean \\
\hline \multirow{2}{*}{ Pre-test } & EC & 49 & 16.72 & \multirow{2}{*}{ Post-test } & EC & 49 & 19.26 \\
\cline { 2 - 5 } & CC & 51 & 16.77 & & CC & 51 & 17.44 \\
\hline
\end{tabular}

Table 2 shows that the means between the writing pre-test and writing post-test are different in EC and the result of writing post-test is higher than that of writing pre-test and the differences are significant. This proves that writing proficiency has greatly been enhanced. The comparison analysis proves that formative assessment can help students improve their writing proficiency.

\section{Conclusion}

This paper proves that the formative assessment has a positive influence on English writing teaching. Through the formative assessment, students' writing proficiency has been greatly improved. It shows that the formative assessment is more effective than the summative assessment. The carrying-out of formative assessment in the experimental class not only enhances students' writing learning but also improves teacher's teaching. Formative assessment helps students improve their writing proficiency. Formative assessment focuses on the whole writing process rather than the products of writing. So students should pay their attention to the process when the self-assessment and peer-assessment are conducted. Fully understand their advantages and disadvantages, students can build learning goals and change their strategies to improve their writing proficiency. 
*Corresponding author, Dongjin, Li, 794494185@qq.com.

\section{Acknowledgement}

This paper has been sponsored by Guangdong Undergraduate College Higher Education Teaching Reform Project of 2016 ("Research on the Construction of Mobile Mooc for College English Majors"; Higher Education Correspondence of Department of Education of Guangdong Province [2016] 236) and Humanities and Social Sciences Fund Program of Ministry of Education of the People's Republic of China (No. 16YJA740050).

\section{References}

[1] M. Scriven, "The Methodology of Evaluation". Washington, D.C.: American Education Research Association, 1967.

[2] B. S. Bloom, "Taxonomy of educational objectives, the classification of educational goals. Handbook I: The Cognitive Domain". Cambridge University Press, pp. 18-20, 1971.

[3] M. Atkin, P. J. Black \& J. Coffey, "Assessment and the National Science Evaluation Standards" (EB/OL). 2003.

[4] J. H. McMillan, "Formative Classroom Assessment: Theory into Practice". New York: Teacher College Press, pp. 105-112, 2007.

[5] D. William, "Embedded Formative Assessment". Bloomington: Solution Tree Press, pp. 108-115, 2011. 